DOI: http://doi.org/10.31617/k.knute.2019-03-19.09

TRENDS OF DIGITAL PROMOTION

\author{
Peresadko G. \\ Doctor in economics, CFO \\ Waste Management Systems Inc, USA \\ Pidlisna O. \\ Candidate of sciences (Ph.D.) in economics, \\ Associate Professor \\ Department of Marketing \\ Kyiv National University of Trade and Economics, Ukraine
}

Keywords: trends, digital promotion, communication tools, information.

Nowadays, it is becoming increasingly important to not just stay on the market, but to achieve an advantage. In this case, companies are actively integrating new technological communication tools in the promotion of their products and services. It may be noted more relevant key trends in the field of digital-promotion.

One of them is the Internet of Things (IoT), which can be effectively used to promote products. It will also allow you to collect useful information about customer behavior and preferences that can be used in new PR companies.

Virtual and Augmented Reality (VR / AR) technologies also help to communicate with customers to promote their products.

Telegram channels are most relevant to trendsetters: journalists, bloggers, and PR people. And also for companies whose business is connected to the Internet.

Through the use of such new products as YouTube, people easily find answers to the questions they are interested in, thereby contacting other people, engaging in deep discussion.

PR-Digital is communication with users through the electronic media.

Network journalism refers to the process of distributed ability to record information, share it and distribute it.

Browsers and social networks allow PR-experts to communicate directly with the target groups

Artificial intelligence can do a lot of thing from writing some news to helping journalists identify patterns and trends from several sources; transform data and speech into text; text in audio and video; isolate emotions from the text; analyze images for objects, faces, text, colors - and so on.

Brand promotion through leaders and popular bloggers is also gaining popularity. 
Augmented reality effectively engages and presents an unforgettable experience. It also helps to unite companies that work in the field of the Internet, as well as other companies that are used to working with old ways of communication.

Offering interactive brand experience or gamification is also used in all types of communications.

Companies that concentrate only on one of the popular social platforms are gaining more and more popularity.

The use of news and promotion bots in journalism is also widespread throughout the world, some gathering news on a given topic, while others help the editorial board to streamline and simplify daily work.

Blockchain is one of the new directions, which makes it possible to use fact-checking online, where users of blockchain media themselves produce fact-checking, and they are responsible for the accuracy of a file.

Despite the new trends and innovations, experts continue to use the older and more familiar habitual methods of broadcasting news, although they know that social media and online marketing reach an audience many times larger than usual offline channels.

\title{
References
}

1. Ворошилов, В.В. Журналистика / В.В. Ворошилов. - М. : СПб. : Михайлов В.А., 2017. - 304 с.

2. The profession of a journalist. [Electronic resource] / 2017. - Mode of access : http://englishwell.org/11099-the-profession-of-a-journalistprofessiya-zhurnalista.html

DOI: http://doi.org/10.31617/k.knute.2019-03-19.10

\section{CONSUMER RIGHTS PROTECTION FROM ILL AFFECTED ADVERTISEMENT OF CHILDHOOD NUTRITION}

\author{
Radchenko, A. \\ Candidate of sciences ( $\mathrm{PhD})$, Associate Professor \\ Department of Trade and Expertise of Goods \\ Kharkiv State University of Food Technology and Trade, Ukraine \\ Grover, $\mathbf{V}$. \\ postgraduate student \\ Michigan State University, USA
}

Keywords: advertising information, childhood nutrition, consumer rights, ill affected advertising, child health. 